body cavity of some of the mites. Presumably, human infection results from the accidental ingestion of infected mites.

This is the twenty-fifth report of human infection with bertiella. Geographically, these reports are mainly from the Eastern Hemisphere-namely, Mauritius (4), India (8), Sumatra (1), Java (2), Borneo (1), Philippines (1), Singapore (1), East Africa (1). In the Western Hemisphere it has been reported once from Cuba, St. Kitts (West Indies), Brazil, Argentina, and Paraguay. The present case is of interest in that the infection was probably acquired in Africa, whence only one case has previously been recorded (Buckley and Fairley, 1950), and in that from the available evidence the boy had probably harboured the worm for about two years.

The subject of bertiella infection to man has been recently reviewed by D'Alessandro, Beaver, and Pallares (1963).

\section{Self-poisoning with Digoxin: Successful Treatment with Atropine}

\section{Brit. med. F., 1967, 3, 660-661}

Self-poisoning with digitalis is uncommon. Lethal doses are massive (McGuire and Richards, 1936; Bergy et al., 1957 ; Johnston and Price, 1960), and death is more likely to follow the ingestion of digitoxin than the more rapidly excreted digoxin. Recovery after very large doses of digoxin (Bernstein et al., 1959) and digitoxin (Bergy et al., 1957 ; Knowles, 1959) has been reported, and it is apparent that survival is more likely when the myocardium is healthy.

\section{CAse Report}

A housewife aged 52 with a long history of depression started taking digoxin in 1961 for lone atrial fibrillation. At 11 a.m. on 18 October 1965 she took $6.25 \mathrm{mg}$. of digoxin. On admission to another hospital the pulse rate was 40 a minute and the blood pressure $90 / 40 \mathrm{~mm}$. $\mathrm{Hg}$; vomiting and diarrhoea decreased after chlorpromazine (100 mg. intramuscularly). On 19 October the pulse rate was $22-25$, and she was transferred to the London Chest Hospital.

She was drowsy and pale, with cold extremities. The pulse was regular at 15, and the blood pressure 120/60. There was slight hepatomegaly, but no other evidence of congestive cardiac failure. She had profuse cold sweats. An electrocardiogram (see Fig., A) showed no atrial activity; the ventricular rhythm was regular, with normal QRS complexes. Serum potassium was $7.9 \mathrm{mEq} / 1$. and blood urea $61 \mathrm{mg} . / 100 \mathrm{ml}$.

While preparations were being made to insert an electrode pacemaker catheter it was decided to try the effect of atropine. Atropine (0.6 mg.) was given intravenously ; the pulse rose to $60 / \mathrm{min}$. within 20 minutes, but then slowed to $36 / \mathrm{min}$. during the next 20 minutes. Atropine $(0.6 \mathrm{mg}$. intravenously) was repeated, and the rate increased to 72. The electrocardiogram (see Fig., B) showed sinus rhythm, with low-voltage $\mathrm{P}$ waves and constant long $\mathrm{P}-\mathrm{R}$ interval $(0.24 \mathrm{sec}$.). Whenever the heart rate fell below 50 , atropine $(0.6 \mathrm{mg}$.) was given intramuscularly; she needed an injection about every five hours for the first 36 hours. During this time the electrocardiogram showed an irregular bradycardia, with variable long $P-R$ interval $(0.24-0.30$ sec.), and variable $P$ wave morphology (see Fig., $C$ ); one tracing after atropine showed atrioventricular dissociation (see Fig., D). On 22 October she reverted to atrial fibrillation, with irregular ventricular response (see Fig., E) and was put back on digoxin.

On admission she had been anuric for over 24 hours. An intravenous drip ( $5 \%$ dextrose) was started, with added sodium bicarbonate; $20 \%$ mannitol was also given (total $300 \mathrm{ml}$. in 14 hours), and urine flow was re-established within half an hour. After an initial rise to $150 \mathrm{mg} . / 100 \mathrm{ml}$. the blood urea rapidly fell to normal ; the serum potassium also fell, to $4.2 \mathrm{mEq} / \mathrm{l}$., and potassium by mouth was started after 18 hours.
We are indebted to Mr. S. Nicholson for the preparation of the specimen and to Dr. M. R. Thomas for the photograph.

C. D. Thompson, M.B., B.CH., General Practitioner.

C. H. JELLARD, B.M., F.C.PATH., DIP.BACT., Director, Public Health Laboratory, Plymouth.

J. J. C. BUCKLEY, D.SC.,

Professor of Helminihology, London School of Hygiene and Tropical Medicine.

\section{REFERENCES}

D'Alessandro, B., Beaver, P. C., and Pallares, R. M. (1963). Amer. 7. trop. Med. Hyg., 12, 193.

Blanchard R. (1891). Mém. Soc. zool. Fr., 4, 186.

Buckley, J. J. C., and Farrley, N. H. (1950). Trans. roy. Soc. trop. Med. Hyg., 44, 2.

Stunkard, H. W. (1940). Amer. F. trop. Med., 20, 305.

She rapidly became more responsive, but remained seriously depressed, and was discharged for further psychiatric treatment after 10 days.

Liver-function tests initially gave abnormal results (21 October : S.G.O.T. 130 units/ml.; S.G.P.T. more than 160 units/ml. 27 October: sulphobromophthalein excretion test: $47 \%$ retention at 25 minutes, and $30 \%$ retention at 45 minutes) but later returned to normal.

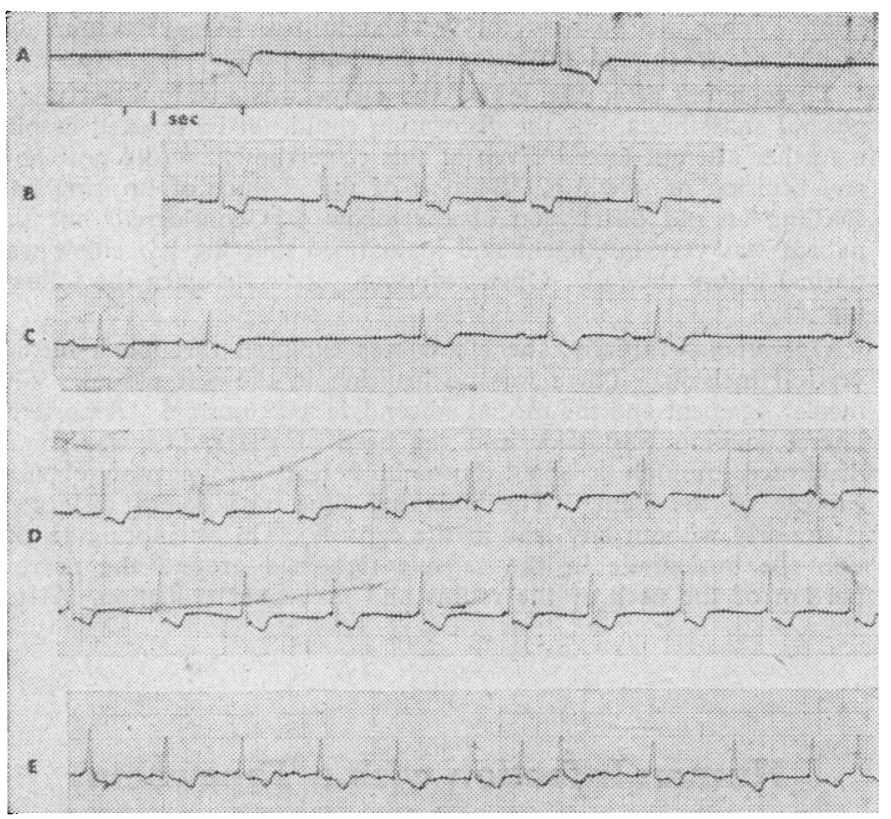

Serial electrocardiograms (all lead II). A, 19 October, before treatment : sinus arrest; extreme nudal bradycardia. B, 19 October, after intravenous atropine: sinus rhythm; low-voltage $\mathrm{P}$ waves; long P-R interval. C, 20
October: wandering pacemaker. D, 20 October, af ter atropine: two consecutive strips showing aurioventricular dissociation. E, 22 October: atrial fibrillation.

\section{Discussion}

The toxic effects of digitalis on the heart have been well reviewed by Burwell and Hendrix (1950), Lown and Levine (1954), Schott (1964), and Dubnow and Burchell (1965). A regular rhythm may occur in the presence of atrial fibrillation as a result of digitalis-induced complete heart block, when the ventricles are controlled by a pacemaker in the main bundle or atrioventricular node below the level of the block; a nodal rhythm may also be associated with atrioventricular dissociation. Sinuatrial block, "wandering pacemaker," and sinus arrest are rare, but were reported by Burwell and Hendrix (1950), and by Bernstein et al. (1959) and Knowles (1959) in their cases of massive overdose. In our patient there was atrial 
asystole with profound slowing due to depression of the nodal pacemaker. Neither ventricular ectopic beats nor paroxysmal atrial tachycardia with block was seen, but may have been prevented by the high serum potassium; Lown and Levine (1954) observed that ectopic beats were rare in digitalis poisoning in patients without heart disease. Hyperkalaemia was probably due to anuria, metabolic acidosis, and the efflux of potassium from the myocardium which occurs with toxic doses of digitalis.

The treatment of digitalis intoxication is based on the withdrawal of digitalis, correction of potassium depletion, and specific measures directed against the arrhythmia (Lown and Levine, 1954; Sodeman, 1965). Sampson et al. (1943) abolished digitalis-induced ventricular ectopic beats with potassium salts given by mouth. Procainamide and betaadrenergic blocking agents (Stock and Dale, 1963 ; Taylor et al., 1964) have been successfully used for digitalis-induced paroxysmal atrial tachycardia with block and ventricular ectopic beats. Calcium ions potentiate digitalis action, and the chelation of calcium with disodium versenate has been recommended by Gubner and Kallman (1957) and Bernstein et al. (1959) in cases of digitalis overdosage.

In our case the blood pressure was well maintained, suggesting that myocardial contractility was not depressed, and that the low cardiac output was due mainly to bradycardia. Atropine was tried as it seemed likely that the extreme bradycardia was due to excessive vagal depression of the nodal pacemaker. It is well known that slowing of the ventricular rate in atrial fibrillation by digitalis is partly mediated by the vagus, though with larger doses the extravagal effect on atrioventricular conduction is more important, so that atropine is relatively ineffective in increasing the ventricular rate (Gold, 1946). In our case, though the dose was massive, the response to atropine was dramatic, but repeated injections were required to maintain a satisfactory heart rate. The nodal rhythm was replaced by a sinus mechanism or wandering pacemaker, and at this stage atropine increased the rate of discharge of both the sinuatrial and the atrioventricular node, with periods of atrioventricular dissociation.

Digitalis is excreted mainly by the kidney (Friedman et al., 1954), small quantities being destroyed in the body or excreted

\section{Self-poisoning with Digitalis Glycosides}

\section{Brit. med. F., 1967, 3, 661-662}

Digitalis and its crystalline derivatives are seldom used in suicidal attempts. Moore (1937) reviewed 1,147 cases of attempted suicide ; poisons were taken in 692 cases, but only one patient used digitalis. Of 16 previously reported cases of selfpoisoning by digitalis (McGuire and Richards, 1936; Tomaszewski and Lapa, 1936 ; Moore, 1937 ; Duvoir et al., 1938 ; Bickel et al., 1951 ; Vuletic and Ivancic, 1952 ; Yu, 1954 ; Bergy et al., 1957; Von Oettingen, 1958; Segre, 1959 ; Bachmann, 1960 ; Bernot and Goldberg, 1960 ; Johnston and Price, 1960 ; Aubertin et al., 1961 ; Thomopoulos and Kokkinos, 1965) only three were fatal (McGuire and Richards, 1936 ; von Oettingen, 1958 ; Johnston and Price, 1960).

The present report describes two patients who poisoned themselves with digitoxin and digoxin respectively, adding one to this very small number of recorded fatal cases.

\section{CASE 1}

A man, aged 59, was brought to the Victoria Infirmary, Glasgow, at 9.30 p.m. on 17 June 1964 . Six hours previously he had in the bile. Prompt restoration of urine flow was thus very important in clearing digoxin from the body.

Impaired liver function in patients with heart disease may be due to hypotension or cardiac failure (Killip and Payne, 1960 ; Richman et al., 1961) but may be caused by digitalis itself. Le Winn (1953) found impaired sulphobromophthalein excretion in patients with gynaecomastia, which was attributed to an oestrogenic effect of long-continued digitalis administration in patients with liver damage. In our patient raised transaminases and increased sulphobromophthalein retention probably resulted from reduced hepatic blood flow, but direct injury by digoxin cannot be ruled out.

We are indebted to Dr. H. G. L. Lloyd-Thomas, who referred this patient to us.

London Chest Hospita,
London E.2.
At present Resident Medical Officer, Westminster Hospital, London
S.W.1.
REFERENCES

Bergy, G. G., Fergus, E. B., and Bruce, R. A. (1957). Ann. intern. Med,, 46,964 .

Bernstein, M. S., Neschis, M., and Collini, F. (1959). New Engl. \%. Med. 261, 961 .

Burwell, W. B., and Hendrix, J. P. (1950). Amer. 7. Med., 8, 640.

Dubnow, M. H., and Burchell, H. B. (1965). Ann. intern. Med., 62, 956.

Friedman, M., St. George, S., and Bine, R. (1954). Medicine (Baltimore), $33,15$.

Gold, H. (1946). 7. Amer. med. Ass., 132, 547.

Gubner, R. S., and Kallman, H. (1957). Amer. 7. med. Sci., 234, 136. Johnston, D. W., and Price, R. V. (1960). Tex. St. F. Med., 56, 429.

Killip, T., and Payne, M. A. (1960) Circulation, 21, 646.

Knowles, R. R. (1959). R.I. med. F., 42, $>92$.

Le Winn, E. B. (1953). New Engl. \%. Med., 248, 316

Lown, B., and Levine, S. A. (1954). Ibid., 250, 771, 819, 866.

McGuire, J.. and Richards, C. E. (1936). Amer. Heart 7. 12, 109.

Richman, S. M., Delman, A. J., and Grob, D. (1961). Amer. Ұ. Med., 30, 211 .

Sampson, J. J., Albertson, E. C., and Kondo, B. (1943). Amer. Heart f., 26, 164

Schott, A. (1964). Postgrad. med. 7., 40, 628.

Sodeman, W. A. (1965). New Engl. 7. Med., 273, 35, 93

Stock, J. P. P., and Dale, N. (1963). Brit. med. F., 2, 1230

Taylor, R. R., Johnston, C. I., and Jose, A. D. (1964). New Engl. 7. Med., 271, 877.

swallowed 100 tablets $(10 \mathrm{mg}$.) of digitoxin, prescribed for his deceased wife. Since her death he had been depressed and had had epigastric discomfort but no other somatic symptoms. There was no history of cardiac or vascular disease.

He was a small thin man, drowsy but in no way distressed. There were no congestive signs or cyanosis. Blood pressure was 100/70. Cardiac rhythm was totally irregular with a ventricular rate of 44 per minute. The heart was not enlarged ; sounds were normal except for a very soft, short systolic murmur localized to the apex. There were no significant abnormalities in other systems. An electrocardiogram taken shortly after admission showed atrial fibrillation and ST-T segment changes in keeping with digitalis effect.

Gastric aspiration yielded no tablets or particles. At 10 p.m. he was given ephedrine $60 \mathrm{mg}$. and potassium chloride $6 \mathrm{~g}$. by mouth. At 11 p.m. the heart rate was about 50. Atropine sulphate $0.5 \mathrm{mg}$. was injected subcutaneously. His general condition remained satisfactory until just after midnight, when he suddenly collapsed in coma. He died about 45 minutes later. Electrocardiograms (lead I) were recorded during this period (see Fig.).

Permission for necropsy was not granted

\section{CASE 2}

A man, aged 22, had rheumatic mitral and aortic valve disease with atrial fibrillation. He had been taking digoxin $0.25 \mathrm{mg}$. twice daily for at least seven years. He had been depressed for several weeks on account of increasing cardiac disability. On the evening of 13 